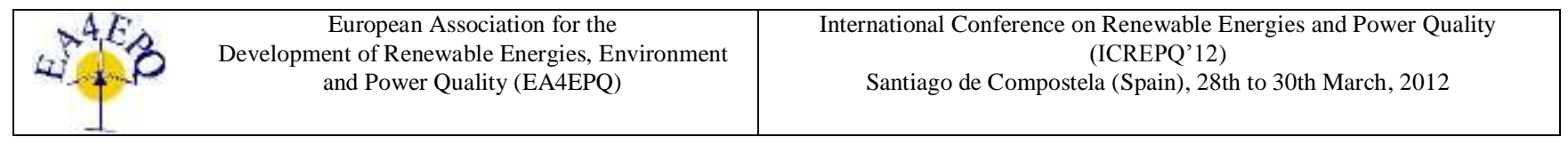

\title{
Development of Solar Powered Boat for Maximum Energy Efficiency
}

\author{
Juraci Carlos de Castro Nóbrega $^{1}$ and Andrej Rössling ${ }^{2}$ \\ ${ }^{1,2}$ Department of Electrical Engineering \\ U.F.A.M., Amazonas University \\ Campus of Aleixo - Manaus, 69033-001, Amazonas (Brazil) \\ Phone/Fax number: +0055 (92)3305 4635, e-mail: jccnobrega@ hotmail.com \\ ${ }^{2}$ ANAST - Naval Architecture Research Unit., Liège University Belgium \\ Address: Institut du Genie Civil, (Bat. B52/3) Chemin des Chevreuils 1, Liège - 4000 \\ +32-4-366 9366, +32-4-366 9133, Andrej.Roessling@gmx.net
}

\begin{abstract}
The present paper shown a work in research and development of a small solar boat design, this work has been developed in Anast/ULG-Belgium as reference for Post-graduate degree in Naval Architecture. The development of a methodology of simple calculation, step by step, for solar boat is shown here, taking in account the use of clean energy, minimum weight of the boat and minimum price of fabrication, for this has been considerate: boat weight; sheet specification; material utilized; appropriate propulsion; necessary quantity of solar panels; quantity of batteries; adequate engine; until to the final commercial price. The Nautilus is a solar powered pleasure boat and basically designed for day-and weekend-trips.
\end{abstract}

\section{Key words}

Solar Energy, Boat Design, Boat Propulsion, Boat Engine and Boat Model.

\section{Introduction}

The Nautilus is a solar powered pleasure boat that satisfies the requirements: transport for 2 persons with their luggage; capacity daily of navigation 25km/Day; with maximum total weight of the unit of $200 \mathrm{~kg}$; for navigation in the lake or river in the day by day or weekend trips.

Because of her special propulsion system he is environmentally friendly and very silent. Her two batteries provide power as well in short cloudy periods. He can be put on a trailer for overland transport.

To keep her as light as possible he is made of composite materials. The Nautilus is basically designed for two peoples and their luggage to day-and weekend-trips. Apart from the four hatches the deck in the fore part is closed. There are two hatches in the bow which are containing the two batteries. The two midship hatches are intended for the luggage of the crew. The engine is an electric outboard motor. That provides a good maneuverability and an easy maintenance.

\section{Bibliographic Revision}

Many works in Solar Boat has been written and many other about small boat too, in this bibliographic revision has been cited the works: Pecen and others wrote "Renewable energy based capstone design applications for an undergraduate engineering technology curriculum", by Deptartament of Industrial and Technology of Univiversity of Northern Iowa USA in 2003 [1].

Jones in 1948 published the book "Small Boat Engine Manual" [2], by Cornell Maritime Press. Duarte in 2007 bublischied "Design of boat powered with electric batery of hidrogeny fuel" [3].

In 1997, has been written the paper about solar power plant, where this work was implanted in the Vila Campina that is a small village in the Amazonas Brazil (NÓBREGA, 1997) [4].

Joore and Wachter, wrote in 2009 "Frisian solar boat design a multi-level innovation analysis" [5]. In the same direction, Leiner wrote "Research solar power boat - data management and online visualization" [6].

Sousa, Simonetti and Norena, Wrote in 2009 "Efficiency optimization of a solar boat induction motor drive" [7]. Bronstein wrote "Taschenbuch der Mathematik" published by Verlag Harri Deutsch", this is a handbook enough used in the Germany's academies [8].

Watson published by Elsevier, "Practical Ship Design" [9]. Finally Spagni, published in 1994 "Marinetech, Research, General Principals and Guidance for the Application of Glass Reinforced Composites Offshore" [10]. 


\section{Boat sheet Specification}

A. Main dimensions

Table I. - Type sizes

\begin{tabular}{|l|l|c|}
\hline Variable & \multicolumn{1}{|c|}{ Description } & $\begin{array}{c}\text { Dimension } \\
{[\mathrm{m}]}\end{array}$ \\
\hline Loa & Length over all & 4.50 \\
\hline Lhull & Length hull & 4.00 \\
\hline Lwl & Length waterline & 3.50 \\
\hline Boa & Breadth over all & 1.92 \\
\hline Bhull & Breadth hull & 1.50 \\
\hline Bwl & Breadth waterline & 1.30 \\
\hline D & Depth & 0.45 \\
\hline T & Draught at design & 0.23 \\
\hline H & Height & 1.65 \\
\hline
\end{tabular}

\section{B. Hydrostatic/ Hydrodynamic}

Table II. - Hydrostatics and hydrodynamics dates

\begin{tabular}{|l|l|l|}
\hline Lsw & Light ship weight & $200[\mathrm{~kg}]$ \\
\hline $\mathrm{Dw}$ & Deadweight & $160[\mathrm{~kg}]$ \\
\hline Vdesign & $\begin{array}{l}\text { Volume at design } \\
\text { draught }\end{array}$ & $0.360\left[\mathrm{~m}^{3}\right]$ \\
\hline $\mathrm{P}$ & Density of freshwater & $1000\left[\mathrm{~kg} / \mathrm{m}^{2}\right]$ \\
\hline$\Delta$ design & $\begin{array}{l}\text { Displacement at design } \\
\text { draught }\end{array}$ & $360[\mathrm{~kg}]$ \\
\hline $\mathrm{Cb}$ & Block coefficient & 0.345 \\
\hline $\mathrm{Fn}$ & Froude number & 0.358 \\
\hline $\mathrm{Gm}$ & Gm for heel $\varphi=0^{\circ}$ & $0.12[\mathrm{~m}]$ \\
\hline
\end{tabular}

\section{Propulsion}

Table III. - Propulsion dates

\begin{tabular}{|l|l|l|}
\hline & \multicolumn{1}{|c|}{ Size } & \multicolumn{1}{c|}{ Appearance } \\
\hline Vmax & Maximum speed & $4[\mathrm{kn}]$ \\
\hline Pmax & Max. Engine power output & $2.7[\mathrm{kw}]$ \\
\hline $\mathrm{A}$ & Area solar panels & $7\left[\mathrm{~m}^{2}\right]$ \\
\hline $\mathrm{U} / \mathrm{C}$ & $\begin{array}{l}\text { Voltage and capacity of the } \\
\text { 2 batteries }\end{array}$ & $24[\mathrm{~V}] / 84[\mathrm{Ah}]$ \\
\hline
\end{tabular}

\section{Boat material}

In order to not exceed the $200 \mathrm{~kg}$ limit for the light ship weight (LSW) it was necessary to use light composite materials. This unfortunately made the Nautilus quit expensive.

Table IV. - Boat material dates

\begin{tabular}{|c|l|l|l|l|l|l|}
\hline Resin & $\begin{array}{l}\text { Reinfor- } \\
\text { Cement }\end{array}$ & $\begin{array}{l}\text { Density } \\
{\left[\mathrm{kg} / \mathrm{m}^{3}\right]}\end{array}$ & $\begin{array}{c}\text { Tensile } \\
\text { Strength } \\
{[\mathrm{Mpa}]}\end{array}$ & $\begin{array}{c}\text { Tensile } \\
\text { Modulus } \\
{[\mathrm{Gpa}]}\end{array}$ & $\begin{array}{c}\text { Comp. } \\
\text { Strength }\end{array}$ & $\begin{array}{c}\text { Approx. } \\
\text { Cost } \\
{[€ / \mathrm{kg}]}\end{array}$ \\
\hline Epoxy & $\begin{array}{l}\text { Aramid } \\
\text { WR }\end{array}$ & 1330 & 517 & 31 & 172 & 20.9 \\
\hline Polyester & $\begin{array}{l}\text { E- } \\
\text { Glass } \\
\text { uni }\end{array}$ & 1800 & $\begin{array}{l}410- \\
1180\end{array}$ & 1241 & $\begin{array}{l}210- \\
480\end{array}$ & 1.8 \\
\hline
\end{tabular}

Hull, bulkheads, pillars, deck, seats and roof are out of the very light Aramid WR. This has relative good material characteristics compared to the weight. The keel which has to contain the main forces and moments is out of the very strong E-Glass uni material.

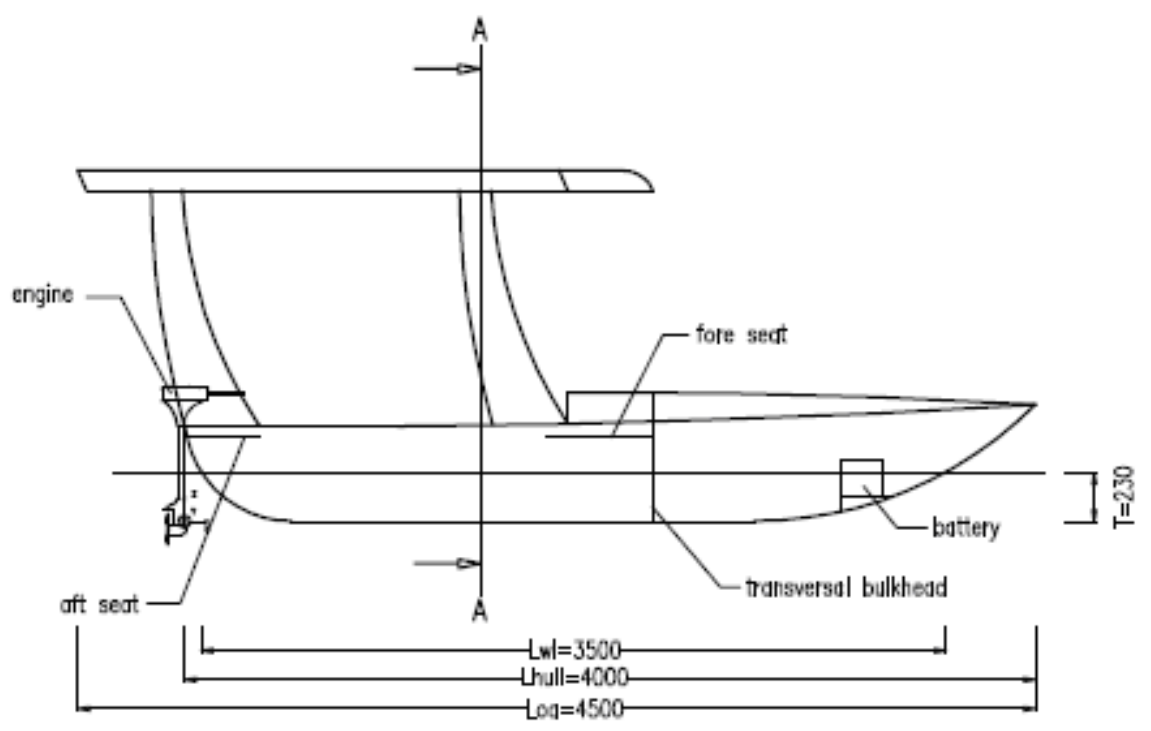

Fig. 1. General view of Solar Boat dimension in centimeters 


\section{Boat Weight}

For the determination of the weights was the hull shape approximated with geometrical surfaces like ellipses and parabolas and also with geometrical bodies like ellipsoids and paraboloides. For the preliminary design the precision of this method should be enough. For the following design steps however more accurate calculation methods are necessary like e.g. SIMPSON.

Table V. - Weight dates

\begin{tabular}{|l|c|c|c|c|c|c|}
\hline Element & $\begin{array}{c}\text { Surface } \\
{\left[\mathrm{m}^{2}\right]}\end{array}$ & $\begin{array}{c}\text { Thickness } \\
{[\mathrm{m}]}\end{array}$ & $\begin{array}{c}\text { Volume } \\
{\left[\mathrm{m}^{3}\right]}\end{array}$ & $\begin{array}{l}\text { Density } \\
{\left[\mathrm{kg} / \mathrm{m}^{3}\right]}\end{array}$ & Material & $\begin{array}{c}\text { Mass } \\
{[\mathrm{kg}]}\end{array}$ \\
\hline Hull aft & 6.86 & 0.005 & 0,0343 & 1330 & $\begin{array}{c}\text { Aramid } \\
\text { wr }\end{array}$ & 5.62 \\
\hline Hull fore & & 0.005 & 0,0030 & 1330 & $\begin{array}{c}\text { Aramid } \\
\text { wr }\end{array}$ & 4.07 \\
\hline Flat keel & 0.21 & 0.02 & 0,0042 & 1800 & $\begin{array}{c}\text { E-glass } \\
\text { uni }\end{array}$ & 7.54 \\
\hline $\begin{array}{l}\text { Bulkhead } \\
\text { trans. }\end{array}$ & 0.49 & 0.005 & 0,0024 & 1330 & $\begin{array}{c}\text { Aramid } \\
\text { wr }\end{array}$ & 3.28 \\
\hline $\begin{array}{l}\text { Bulkhead } \\
\text { long. }\end{array}$ & 0.83 & 0.005 & 0,0041 & 1330 & $\begin{array}{c}\text { Aramid } \\
\text { wr }\end{array}$ & 5.52 \\
\hline Deck & 2.76 & 0.004 & 0,0082 & 1330 & $\begin{array}{c}\text { Aramid } \\
\text { wr }\end{array}$ & 4.68 \\
\hline Roof & 4.27 & 0.003 & 0,0128 & 1330 & $\begin{array}{c}\text { Aramid } \\
\text { wr }\end{array}$ & 7.04 \\
\hline Pillar & & 0.003 & 0,0007 & 1330 & $\begin{array}{c}\text { Aramid } \\
\text { wr }\end{array}$ & 1.01 \\
\hline Seat & 0.53 & 0.005 & 0,0007 & 1330 & $\begin{array}{c}\text { Aramid } \\
\text { wr }\end{array}$ & 1.01 \\
\hline
\end{tabular}

Table VI. - Total weight

\begin{tabular}{|c|c|}
\hline Element & $\begin{array}{c}\mathrm{Mi} \\
{[\mathrm{kg}]} \\
\end{array}$ \\
\hline Hull & 49.69 \\
\hline Flat keel & 7.54 \\
\hline Deck & 14.68 \\
\hline Bulkhead transversal & 3.28 \\
\hline Bulkhead longitudinal & 5.52 \\
\hline Roof & 17.04 \\
\hline Solar panel deck & 16,56 \\
\hline Solar panel roof & 25.62 \\
\hline 2 fore pillars & 2.01 \\
\hline 2 aft pillars & 2.01 \\
\hline Engine & 22.00 \\
\hline 2 batteries & 30.00 \\
\hline Fore seat & 1.01 \\
\hline Aft seat & 1.01 \\
\hline$\sum=$ & 198 \\
\hline
\end{tabular}

The difference of $2 \mathrm{~kg}$ between the denoted $200 \mathrm{~kg}$ LSW in the data sheet and the $198 \mathrm{~kg}$ LSW in this table is used as a reserve. This documentation contains a preliminary design. For this reason the weights were calculated with simple approximations. That means that there will probably be variations in the weight during the following design stages. The reserve of $2 \mathrm{~kg}$ acts as a security factor to make sure that the total weight of the Nautilus is less than the required $200 \mathrm{~kg}$.

\section{Boat Propulsion}

Significant boats

To approximate the needful power for the propulsion system 6 similar boats were compared to each other. The effort to use the Admiralty coefficient was not effective:

Admiralty coefficient: $\quad \operatorname{Cadm}=\frac{\Delta^{2 / 3} \cdot v^{3}}{P b}$

Used significant boats:

Table VII. - Propulsion dates

\begin{tabular}{|l|l|l|l|l|c|}
\hline \multicolumn{1}{|c|}{ Boat } & $\begin{array}{c}\mathrm{L} \\
{[\mathrm{m}]}\end{array}$ & $\begin{array}{c}\Delta \\
{[\mathrm{kg}]}\end{array}$ & $\begin{array}{c}\mathrm{V} \\
{[\mathrm{kn}]}\end{array}$ & $\begin{array}{c}\mathrm{Pb} \\
{[\mathrm{kw}]}\end{array}$ & Cadm \\
\hline Woolwich 20 & 5.9 & 1000 & 5.8 & 2.4 & 8130 \\
\hline Electric Boat & 4 & 280 & 4.9 & 0.3 & 6784 \\
\hline $\begin{array}{l}\text { Frauscher 560 } \\
\text { Valencia }\end{array}$ & 5.6 & 650 & $/$ & 4.3 & $/$ \\
\hline Frauscher 1500 W & 5.4 & 350 & $/$ & 1.5 & $/$ \\
\hline Terhi (FI) Sea Fun C & 4.06 & 185 & $/$ & 2 & $/$ \\
\hline $\begin{array}{l}\text { Frauscher 600 } \\
\text { Riviera }\end{array}$ & 6 & 1400 & 5 & 4 & 3911 \\
\hline
\end{tabular}

Mean values: $=5.16 \mathrm{~m} ;=644 \mathrm{~kg} ;=5.2 \mathrm{kn} ;=2.4 \mathrm{kw}$

The Admiralty coefficient which is a crude but useful method of estimating power doesn't gave any helpful values in this case. The main reason for that are probably the strong distinctions in the used values. As this method is confined to cases where the change in speed ( $\mathrm{V}$ in $\mathrm{kn}$ ) and displacement $(\Delta$ in $\mathrm{kg})$ is relatively small.

Besides the big distribution from the Admiralty coefficients the table shows that the Nautilus is with a length $\mathrm{L}$ of $4.50 \mathrm{~m}$, a displacement $\Delta$ of $360 \mathrm{~kg}$ and an engine power $\mathrm{Pb}$ of $2.7 \mathrm{kw}$ for a speed $\mathrm{V}$ of $4 \mathrm{knots}$ well equipped.

\section{Solar Energy}

Table VIII. - Solar dates

\begin{tabular}{|l|l|}
\hline \multicolumn{1}{|c|}{ Used values } & \\
\hline Solar constant (terrestrial) & $1 \mathrm{kw} / \mathrm{m}^{3}$ \\
\hline Effectiveness $\eta$ of the solar panels & $20 \%$ \\
\hline Surface of the solar panels & $7.03 \mathrm{~m}^{3}$ \\
\hline Area weight solar panel & $6 \mathrm{~kg} / \mathrm{m}^{3}$ \\
\hline
\end{tabular}

Source : www.solarkonstante.de

The quantity of solar energy in central Europe equals in good weather conditions averagely $1 \mathrm{kw}$ per $1 \mathrm{~m}^{2}$ 
terrestrial surfaces. Mono crystalline solar cells are able to convert $20 \%$ of the incoming solar energy into electrical energy:

$$
\Rightarrow 1 \frac{\mathrm{kW}}{\mathrm{m}^{2}} * 0.20 * 7.03 \mathrm{~m}^{2}=1.41 \mathrm{~kW}
$$

The solar panels on the Nautilus can provide $1.41 \mathrm{kw}$, as illustrate in the equation 2.

\section{Batteries}

The Nautilus contains two batteries of the following type as show in the table IX.

Table IX. - Batteries specification

\begin{tabular}{|l|c|c|c|c|}
\hline Manufacturer & $\begin{array}{c}\text { Voltage/ } \\
\text { Capacity } \\
{[\text { V/Ah] }}\end{array}$ & $\begin{array}{c}\text { Dimensions } \\
\text { (length } \mathrm{x} \text { breath } \mathrm{x} \\
\text { hight) } \\
{[\mathrm{mm}]}\end{array}$ & $\begin{array}{c}\text { Weight } \\
{[\mathrm{kg}]}\end{array}$ & $\begin{array}{c}\text { Price } \\
{[€]}\end{array}$ \\
\hline DETA GEL & $12 / 42$ & $197 \times 166 \times 175$ & 15 & 300 \\
\hline Total & $24 / 84$ & $/$ & 30 & 600 \\
\hline
\end{tabular}

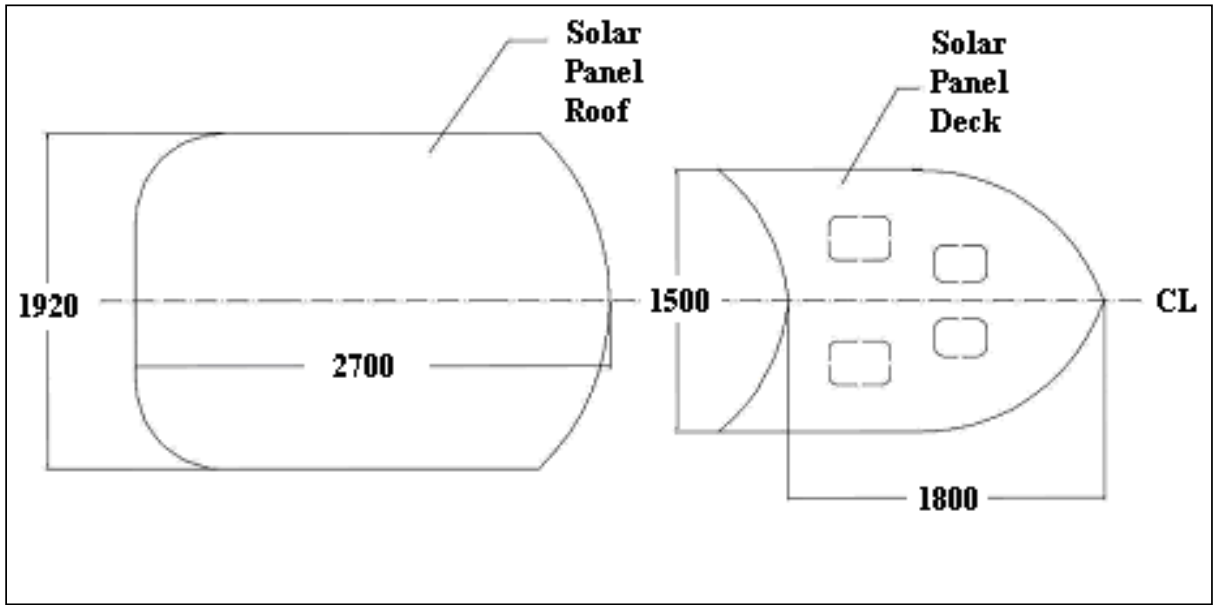

Fig. 2. General view of the solar panels dimension in centimetres

The batteries are installed in the fore part of the boat. One stands on the portside and the other one on starboard. To ensure a good maintenance for each battery is a hatch in the deck installed. With the two batteries the Nautilus can store the solar energy. So she has propulsion even under non-perfect weather conditions.

\section{Engine}

In the Nautilus in development there is a lot of the engines to sell in the commerce, here was chosen the Karvin 2700 engine, nevertheless any other can to be chose.

Table X. - KARVIN 2700

\begin{tabular}{|l|l|}
\hline \multicolumn{1}{|c|}{ Amp hour rating min } & \multicolumn{1}{c|}{80 Ah battery } \\
\hline Battery voltage & $24 \mathrm{~V} / 36 \mathrm{~V} / 48 \mathrm{~V}$ \\
\hline Rpm max. & $900 / 1200 / 1500$ \\
\hline Power max. Kw/Hp & $2.7 / 3.6$ \\
\hline Torque & $27.5 \mathrm{~nm}$ \\
\hline Shaft length & $\begin{array}{l}\text { long shaft } 1(510 \mathrm{~mm}) / \\
\text { short shaft s }(380 \mathrm{~mm})\end{array}$ \\
\hline Continuous regulation & Yes \\
\hline Forward and reverse & Yes \\
\hline Engine weight & 22kg \\
\hline Electronics & $\begin{array}{l}\text { electronic control + } \\
\text { electronic safety key }\end{array}$ \\
\hline
\end{tabular}

Source: www.karvin.eu

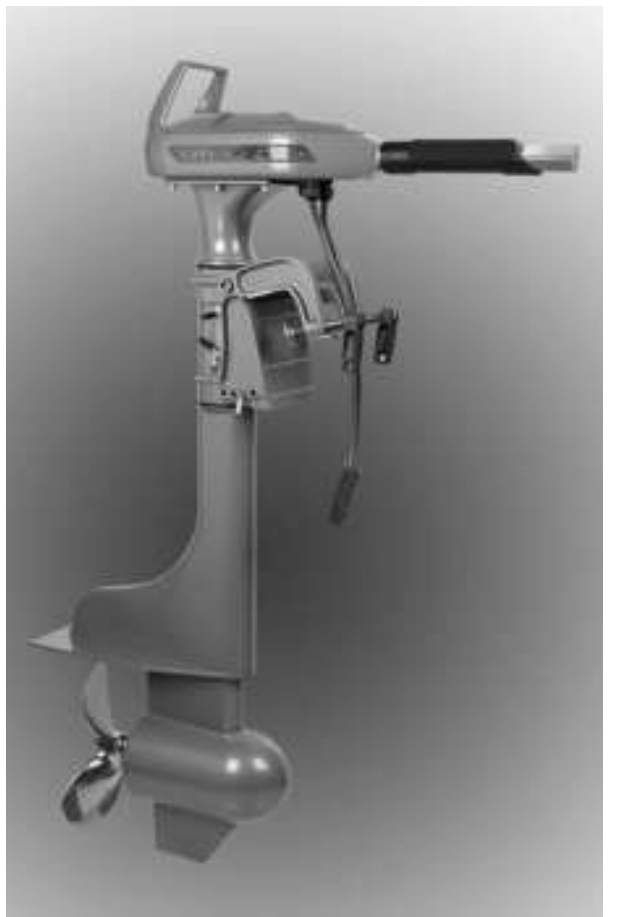

Fig. 3. Karvin 2700 Engine 


\section{Boat Stability}

For the determination of the centers of gravity of the sections valid the same as for the weight. No numerical methods were used during the preliminary design. That results in the fact that all the given data are approximations and may change in the following design steps.

Table XI. - Stability dates

\begin{tabular}{|c|c|c|c|c|c|}
\hline Element & $\begin{array}{l}\mathrm{Mi} \\
{[\mathrm{kg}]}\end{array}$ & $\begin{array}{l}\text { Xcgi } \\
{[\mathrm{m}]}\end{array}$ & $\begin{array}{c}\text { Mi x } \\
\text { Xcgi } \\
{[\text { kg.m] }} \\
\end{array}$ & $\begin{array}{l}\text { Zcgi } \\
{[\mathrm{m}]}\end{array}$ & $\begin{array}{c}\text { Mi x } \\
\text { Zcgi } \\
\text { [kg.m] }\end{array}$ \\
\hline Hull & 49.69 & 1.77 & 88.05 & 0.15 & 7.50 \\
\hline Flat keel & 7.54 & 2.07 & 15.59 & 0.08 & 0.57 \\
\hline Deck & 14.68 & 2.93 & 32.23 & 0.45 & 6.61 \\
\hline $\begin{array}{l}\text { Bulkhead } \\
\text { trans. }\end{array}$ & 3.28 & 2.80 & 6.57 & 0.32 & 1.05 \\
\hline $\begin{array}{l}\text { Bulkhead } \\
\text { long. }\end{array}$ & 5.52 & 2.91 & 16.06 & 0.25 & 1.40 \\
\hline Roof & 17.04 & 1.00 & 17.04 & 1.65 & 28.11 \\
\hline \begin{tabular}{|l|} 
Solar \\
panel deck
\end{tabular} & 16.56 & 2.93 & 48.46 & 0.45 & 7.45 \\
\hline $\begin{array}{l}\text { Solar } \\
\text { panel roof }\end{array}$ & 25.62 & 1.00 & 25.62 & 1.65 & 42.27 \\
\hline $\begin{array}{l}2 \text { fore } \\
\text { pillars }\end{array}$ & 2.01 & 1.50 & 3.02 & 0.85 & 1.71 \\
\hline $\begin{array}{l}2 \text { aft } \\
\text { pillars }\end{array}$ & 2.01 & 0.06 & 0.12 & 0.85 & 1.71 \\
\hline Engine & 22.00 & 3.18 & 69.96 & 0.23 & 5.06 \\
\hline 2 batteries & 30.00 & 2.80 & 84.00 & 0.09 & 2.70 \\
\hline Fore seat & 1.01 & 1.83 & 1.84 & 0.40 & 0.40 \\
\hline Aft seat & 1.01 & 0.18 & 0.18 & 0.40 & 0.40 \\
\hline 2 persons & 160.00 & 1.00 & 160.00 & 1.20 & 192.00 \\
\hline$\Sigma=$ & 54.29 & \multirow[b]{2}{*}{ 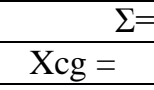 } & \begin{tabular}{|l|l|}
582.09 \\
\end{tabular} & $\Sigma=$ & 298.93 \\
\hline & & & 1.63 & $\mathrm{Zcg}=$ & 0.84 \\
\hline
\end{tabular}

\section{Calculation of GM (heel $\varphi=0^{\circ}$ )}

$$
\mathrm{GM}=\mathrm{KB}+\mathrm{BM}-\mathrm{KG}
$$

The distance between the base line $\mathrm{K}(\mathrm{Z}=0 \mathrm{~m})$ and the center of buoyancy in z-direction (ZCB) equals to:

$$
\mathrm{KB} \sim \frac{2}{3} \mathrm{~T}-\frac{2}{3} * 0.23 \mathrm{~m}-0.15 \mathrm{~m}
$$

The distance between the center of buoyancy in $\mathrm{z}$ direction (ZCB) and the metacenter (M) equals to:

$$
\mathrm{BM}=\frac{\mathrm{I}_{\mathrm{T}}}{\mathrm{V}} \sim \frac{\mathrm{L} \cdot \widehat{\mathrm{B}}^{3}}{12 \cdot \mathrm{V}}=\frac{3.5 \mathrm{~m} *(1.0 \mathrm{~m})^{3}}{12 \cdot 0.360 \mathrm{~m}^{3}}=0.81 \mathrm{~m}
$$

So the initial stability is:

$$
\mathbf{G M}=\mathrm{KB}+\mathrm{BM}-\mathrm{KG}=(0.15+0.81-0.84) \mathrm{m}=\mathbf{0 . 1 2} \mathbf{m}
$$

The initial stability was calculated for the case that to persons with a weight of $80 \mathrm{~kg}$ per person stand in the aft part of the Nautilus. This was defined as the worst possible loading case. With a GM of $0.12 \mathrm{~m}$ is the initial stability good.

\section{Strength}

Strength Considering the longitudinal strength the flat keel $(50 \mathrm{~mm} \times 20 \mathrm{~mm})$ is the most important component of the Nautilus. She is designed for lakes and rivers. So she will not be subject to the strong torsion-and bending moments which can be created from heavy sea motions. But an inconvenient distribution of the Deadweight in the Nautilus can also cause significant torsion and bending moments. The main structure that provides strength in the hull of the boat consists of:

- The flat keel (general longitudinal strength)

- The transversal bulkhead (receives torsion moments from the hull)

- The seats (prevent the twist of the hull through the reduction of the deck opening degree)

- The longitudinal bulkhead (prevents the warping of the transversal bulkhead and connects the keel with the deck)

- And the deck (prevents the twist of the hull and receives also the bending moments)

Besides a possible inconvenient distribution of the Deadweight the overland transport on a trailer is another critical condition regarding to the strength. In that case the whole weight of the Nautilus rests on a few points with a relatively small area. So there can be strong area forces on the hull. Those can be increased through additional impulse forces caused by bad road conditions during the overland transport. So during the transport the forces should be introduced in the hull basically through the flat keel and from the side through the transversal bulkhead. The area of the support points should be as big as possible. Due to optical-and strength-reasons the cross section of the pillars is relatively big and ellipses shaped.

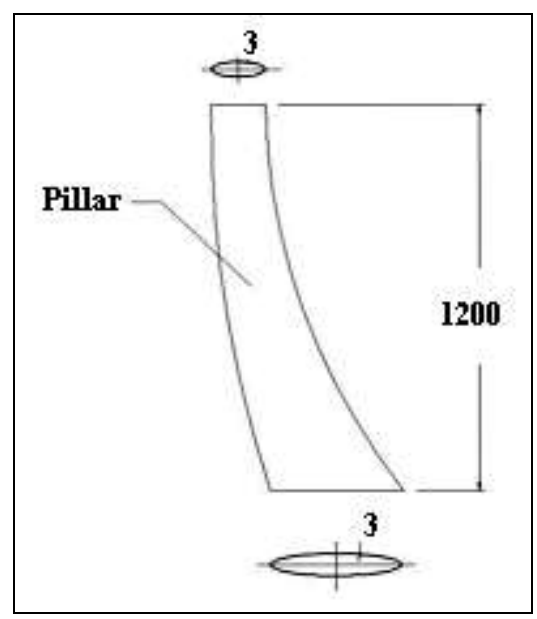

Fig. 4. Cross section of the pillars dimension in centimeters 


\section{Construction Mode}

The hull can be produced in a negative form or in a positive form. In which several layers of the material can be put on top of each other. If the hull is ready and separated from the negative form the two bulkheads which can be produced as one single part can be glued in the hull. In the next step the deck (with the four holes for the hatches) must be glued on the hull.

The pillars can be made around a positive form.

When they are ready and separated from their form they can be installed on the hull. The connections between the pillars and the deck and the pillars and the roof are also glue connections. Like the hull the roof can be produced in a positive or negative form.

When all composite parts are connected the solar panels can be bond on deck, roof and the four hatch covers. The montage of the four hatch covers is the next step. After that the electricity must be installed.

That means the batteries and wires get assembled. (It may be favorable to install the batteries in the hull before the installation of the deck.) The last step is to install the engine.

\section{Price}

Because of the used materials and the solar concept the Nautilus is with a price of about $12000 €$ relatively expensive compared to boats with similar main dimensions.

Table XII. - Price

\begin{tabular}{|c|c|c|}
\hline Element & $\begin{array}{c}\mathrm{M} \\
{[\mathrm{kg}]}\end{array}$ & $\begin{array}{c}\text { Price } \\
{[€]}\end{array}$ \\
\hline Aramid WR & 92.28 & 1930 \\
\hline E- Glass uni & 7.54 & 14 \\
\hline Engine & 22 & 200 \\
\hline 2 batteries & 30 & 600 \\
\hline Solar panels & 7.03 & 9100 \\
\hline & $\Sigma=$ & 11844 \\
\hline
\end{tabular}

\section{Conclusion}

The used approximations are not very exact. Because of that it is possible that the real total weight is higher than the required $200 \mathrm{~kg}$. To keep the LSW lower than $200 \mathrm{~kg}$ will probably be the most difficult challenge during the following design stages. A reason for that may also be the fact that the choice of the thicknesses for the material is based on sense. So the thicknesses may change significant after a more detailed view on the strength parameters.

During the design process it turned out that the area for the solar panels should be bigger so that the engine can run with maximum power. Another possibility is to install a smaller engine.

\section{References}

[1] Pecen, R.; Hall, T.; Chalkiadakis, F.; Zora A.; "Renewable energy based capstone design applications for an undergraduate engineering technology curriculum", Dept. of Ind. Technol., Univ. of Northern Iowa, Cedar Falls, IA, USA, (2003).

[2] Cecil M. , Jones, "Small boat engine manual", New York, Cornell Maritime Press, (1948).

[3] Duarte, Filipe M. B. Projecto de uma embarcação com propulsão eléctrica e pilha de combustível a hidrogênio, Dissertação de Mestrado em Engenharia Naval, , Universidade de Tecnologia de Lisboa, (2007).

[4] Nóbrega, J. and Others, "Perspectivas de redução de consumo de combustível em sistemas isolados através do uso eficiente de energia: utilização de sistemas híbrido fotovoltaico", SBQEE’97, São Paulo, Brazil, (1997).

[5] P. Joore and A. Wachter, "Frisian solar boat design a multilevel innovation analysis", (2009).

[6] R. Leiner, "Research solar power boat - data management and online visualization", (2009).

[7] G.C.D, Sousa, D.S.L., Simonetti, and E.E.C. Norena, "Efficiency optimizations of a solar boat induction motor drive", (2009).

[8] I.N. Bronstein, Taschenbuch der Mathematik, published by Verlag Harri Deutsch, Germany (2004).

[9] D.G.M. Watson, Practical Ship Design, published by Elsevier, (2002).

[10] D.A. Spagni, Marinetech, Research, General Principals and Guidance for the Application of Glass Reinforced Composites Offshore, (1994). 